\title{
REVIEW TENTANG DESIGN MONETARY POLICY RULE UNTUK INDONESIA
}

\author{
G. Sujana Budhiasa
}

Fakultas Ekonomi Universitas Udayana, Denpasar-Bali.

\begin{abstract}
The development monetary policy rule has become a fashionable macroeconomic modeling as pioneering by Taylor (1993) Indonesia is one of emerging market countries that has advantages in adopting the Taylor monetary policy rule that was implementing together with inflation targeting framework dealing with the central bank law of Bank Indonesia on the new task for stabilizing the domestic currency, so that the new law of Bank Indonesia might be appropriate to adopt inflation targeting framework (Taylor, 2000).

According to the new law, Bank Indonesia is obliged to announce the inflation plan at the beginning of the year to the public. Alamsyah, Agung and Zulverdy (2001), point-out that Bank Indonesia has become implemented the inflation targeting framework because it was obligated by the new law of Bank Indonesia.

Practical of inflation targeting framework (ITF) in many countries adopted Taylor modified monetary policy rules with using many anchors. Svensson (1999) argued that because uncertain of some economic variables behavior, using interest rate as single anchor as recommended by Taylor rules can be robustness.

Bank Indonesia have practical a single anchor called SBI Rate in implementing the inflation targeting framework. SBI Rate is recommended by McNelis (1999) and also Darsono et. al (2002) as the single instrument rule for managing inflation gap and output gap in Indonesia.

This paper is intends to study the development of policy rule theory and its possibility of those model developed for implementing at Bank Indonesia macroeconomic model.
\end{abstract}

Keywords: monetary policy, domestic currency, inflation targeting.

Kebijakan moneter Bank Indonesia telah mengalami berbagai perubahan sejalan dengan perkembangan ekonomi Indonesia. Sejak awal tahun 1970, Bank Indonesia telah merubah arah kebijakan moneter dari pengendalian moneter secara langsung (direct control) terhadap pagu kredit dan batas penetapan tertinggi suku bunga, menjadi kebijakan yang bersifat open market operation. Perubahan kebijakan moneter dari pola direct control ke bentuk open market operation ini pada hakekatnya kebijakan moneter diarahkan dengan mempergunakan instrument kebijakan money aggregate yang ditujukan untuk mempengaruhi jumlah uang beredar.

IMF pada tahun 1997 telah merekomendasikan kepada Bank Indonesia untuk mempergunakan policy rule yang berbasis money aggregate dengan mempergunakan k-percent 
monetary growth dalam rangka menciptakan stabilitas moneter di Indonesia. Sejalan dengan tugas pokok Bank Indonesia yang termuat pada UU No. 23 Tahun 1999, maka kebijakan policy rule Bank Indonesia telah mengalami perubahan dari pendekatan money aggregate ke pola Taylor rule yang berbasis pada pendekatan suku bunga sebagai nominal anchor.

Rangkuman hasil penelitian yang dilakukan oleh Direktorat Riset Bank Indonesia, sebagaimana dilaporkan oleh Aulia Pohan (2008), menyatakan bahwa kebijakan money aggregate telah mulai ditinggalkan oleh banyak negara, karena perkembangan yang sangat pesat dari financial innovation serta arah perubahan persaingan pasar keuangan internasional, telah menyebabkan income multiplier dan money multiplier tidak lagi dapat dijadikan instrument kebijakan moneter yang handal dimasa depan.

Penelitian yang dilakukan MacNelis untuk Bank Indonesia pada tahun 1999, (McNelis, 1999), telah merekomendasikan perubahan penggunaan kebijakan moneter dari kebijakan instrumen money aggregate menuju pendekatan policy rule berbasis tingkat suku bunga dengan framework inflation targeting.

Meskipun rekomendasi McNelis tidak serta merta dilaksanakan pada tahun 1999 sebagai kerangka baru pendekatan kebijakan moneter, tetapi paling sedikit penelitian McNelis telah membuka penelitian berikutnya secara lebih intensif tentang kemungkinan penerapan inflation targeting Bank Indonesia dimasa depan. Beberapa studi yang terkait dengan kajian inflation targeting framework di Indonesia antara lain disampaikan oleh Alamsyah et. al (2001), serta Darsono et, al (2002) maupun Tanuwidjaja dan Choy (2005).

Rekomendasi McNelis untuk Bank Indonesia merupakan tahapan awal pembelajaran bagi Bank Indonesia untuk meng-implementasikan secara bertahap menjadi kebijakan monetary policy rule Bank Indonesia. Kompleknya persoalan ekonomi Indonesia dan sejumlah kondisi yang penuh dengan ketidak-pastian bersamaan dengan penyelenggaraan otonomi pemerintahan daerah, telah menyebabkan Bank Indonesia mempergunakan pendekatan lite inflation targeting framework yang mempergunakan instrumen moneter bersifat multi-anchor (Pohan, 2008).

Pendekatan konsep monetary policy rule yang sejalan dengan policy rule sebagaimana digagas oleh Taylor tercatat mulai dilaksanakan sejak bulan juni 2005, yang dikenal sebagai inflation targeting framework. Beberapa sign yang dapat dijadikan pedoman bahwa suatu Bank Sentral dinyatakan sebagai penganut inflation targeting framework adalah bahwa target inflasi 
wajib di umumkan oleh Bank Sentral pada setiap permulaan tahun anggaran, serta penjelasan secara terbuka dari Bank Sentral yang dilaksanakan untuk mencapai sasaran akhir dari target inflasi tersebut.

\section{DISCRETION VERSUS RULE}

Perdebatan akademik yang berkembang disekitar awal tahun 1990-an berkaitan dengan discretion (kebijakan) dan policy rule. Taylor (1993) telah menggagas policy rule yang mempergunakan suku bunga sebagai fungsi reaksi atas sejumlah perlakuan khusus pada target inflasi yang ingin dicapai dan target pertumbuhan output khususnya dalam jangka pendek. Policy rule Taylor (1993) :

$$
i_{t}=r^{*}+\pi_{t-1}+\gamma_{2}\left(\pi_{t-1}-\pi^{T}\right)+\gamma_{2}\left(y_{t-1}-y_{t-1}^{*}\right)
$$

\section{Dimana:}

I $\quad=$ tingkat suku bunga (SBI rate)

$\mathrm{r}^{*} \quad=$ real interest rate

$\Pi, \Pi^{\mathrm{T}} \quad=$ pergerakan inflasi, target inflasi

$\mathrm{y}, \mathrm{y}^{*}=$ deviasi output gap yang menggambarkan besarnya kesenjangan antara pergerakan nominal GDP dengan GDP potensial.

Mengikuti Taylor (1993), kerangka kebijakan monetary policy rule mempergunakan singleanchor tingkat suku bunga sebagai fungsi reaksi, yang nilainya ditentukan berdasarkan target pembobotan dari deviasi inflasi $\left(\Pi-\Pi^{\mathrm{T}}\right)$ dan deviasi output gap $\left(\mathrm{y}-\mathrm{y}^{*}\right)$.

Bernanke dan Reinhart (2004) memberi interpretasi dari monetary policy rule yang digagas oleh Taylor sebagai model policy rule yang memuat didalamnya dual-mandate, yaitu inflasi dan output. Disatu pihak, apabila pembobotan deviasi inflasi ditetapkan lebih kecil dari pembobotan output gap, maka itu berarti dalam jangka pendek perekonomian diarahkan untuk mencapai stabilitas ekonomi dengan akibat akan terjadi lost function dari target peningkatan produksi dan lapangan kerja. Sebaliknya, apabila pembobotan output gap ditetapkan lebih kecil dari deviasi inflasi, maka perekonomian akan mengalami tekanan inflasi dengan akibat ketidak-stabilan ekonomi serta membawa serta biaya perekonomian tinggi.

McNelis (1999) merekomendasikan kepada Bank Indinesia untuk memberi pembobotan yang lebih besar pada deviasi output, dengan pertimbangan adanya inflationary bias. Rekomendasi McNelis apabila dilaksanakan oleh Bank Indonesia, akan menyebabkan sulitnya 
dapat dicapai realisasi pertumbuhan inflasi setingkat dengan target inflasi yang diumumkan pada awal tahun anggaran oleh Bank Indonesia.

Alamsyah et. al (2001) menyatakan bahwa Bank Indonesia wajib mengumumkan target inflasi pada setiap awal tahun anggaran, sebagai konsekuensi dari kerangka kebijakan moneter yang menganut rezime inflation targeting framework. Apabila realisasi inflasi pada akhir tahun anggaran berada diatas target yang ditetapkan oleh Bank Indonesia, maka Bank Indonesia dapat dinyatakan sebagai lembaga yang tidak credible.

Berbeda dengan rekomendasi yang disampaikan McNelis untuk Bank Indonesia, maka penelitian Darsono, et al (2002) justru merekomendasikan kebijakan untuk memberi pembobotan deviasi inflasi yang lebih rendah dibandingkan dengan deviasi output. Darsono yang juga sejalan dengan Debelle (2001), memandang bahwa realisasi inflasi yang rendah dan stabil perlu diwujudkan oleh Bank Indonesia dalam rangka mengantarkan Bank Indonesia menjadi otoritas moneter yang memiliki credibility untuk pada gilirannya akan menciptakan dengan sendirinya ekspektasi inflasi yang makin kuat dimasa depan.

Kebijakan monetary policy rule yang digagas oleh Taylor (1993) bersifat backward looking, yang kemudian dilakukan modifikasi dengan lebih mengarahkan model Taylor menjadi policy rule yang bersifat forward looking. Ball (1998), serta Batini dan Haldane (1999), serta Tanuwidjaja dan Choy (2005) adalah sejumlah peneliti yang merekomendasikan pentingnya memperhatikan forward looking expectation dalam perumusan sebuah kebijakan monetary policy rule.

Penelitian monetary policy rule Bank Indonesia yang dilakukan oleh Tanuwidjaja dan Choy (2005), menemukan bahwa ekspektasi inflasi di Indonesia sebagian besar masih bersifat backward looking, hanya sekitar $21 \%$ dari ekspektasi inflasi bersumber dari ekspekasi forward looking. Hal ini mengindikasikan bahwa bahwa monetary policy rule yang diterapkan di Indonesia belum mencapai sasaran secara optimal sebagaimana diharapkan sejalan dengan peran Bank Indonesia sebagai pengendali stabilitas ekonomi di Indonesia.

\section{Pengembangan Policy Rule yang Relevan dengan Ekonomi Indonesia}

Bulan juni 2005, Bank Indonesia telah menyatakan secara mantap menerapkan regime inflation targeting framework, sebagai kerangka pengendalian kebijakan moneter untuk mencapai sasaran akhir dari pertumbuhan inflasi (Sukada, 2008). Kerangka Kebijakan moneter inflation targeting framework yang mempergunakan operasional suku bunga sebagai single-anchor, telah 
diyakini dapat membantu tugas Bank Indonesia untuk mencapai stablilitas perekonomian Indonesia. (Direktorat Riset Bank Indonesia, 2004).

Sebuah pemodelan monetary policy rule sebagaimana digagas oleh Taylor tentu sangat tidak memadai untuk dipergunakan sebagai design untuk perumusan kebijakan moneter di Indonesia. Batini dan Haldane (2001) telah mengupayakan pengembangan model ekonomi makro berskala kecil untuk dapat mencakup lebih banyak informasi ditengah ketidak-pastian yang tinggi dari perkembangan ekonomi akibat dari berbagai shocks yang terjadi secara tidak terduga. Upaya penyusunan sebuah pemodelan ekonomi makro monetary policy rule menjadi bertambah sulit, disebabkan oleh gerak perubahan dinamis dari jenis transmisi instrumen moneter serta parameter yang membentuknya.

Dapat disimpulkan bahwa Bank Indonesia dewasa ini sedang berusaha mencari bentuk pemodelan yang dapat difungsikan secara optimal untuk mencapai sasaran stabilitas ekonomi jangka pendek, dengan tidak mengorbankan keseimbangan jangka panjang untuk mencapai pertumbuhan angka inflasi yang cukup rendah dan stabil dengan tidak terlalu besar mengakibatkan lost function dari pertumbuhan produksi dan kesempatan kerja.

MacNelis (1999) dan Darsono et al (2002) telah memberikan gambaran, betapa kerangka kebijakan monetary policy rule dalam implementasinya telah menghasilkan rekomendasi yang berbeda. Perbedaan pendapat dari kedua peneliti diatas, juga sekaligus memberikan gambaran tentang perdebatan akademik yang masih berkepanjangan dalam menentukan pilihan apakah akan dilaksanakan sasaran akhir pencapaian inflasi yang rendah dengan akibat mengorbankan potensi produksi dan lapangan kerja atau memberi kelonggaran ruang gerak inflasi dengan harapan dapat memberi ruang gerak kepada potensi produksi dan angkatan kerja. Pilihan jangka pendek ini akan sangat ditentukan oleh kebijakan Bank Sentral serta aspirasi politik yang melatar belakangi Bank Sentral dalam merumuskan target kebijakan moneternya.

Ketika Bank Sentral memilih untuk mendesign respon kebijakan moneter untuk mencapai sasaran inflasi yang rendah dan stabil dengan mengabaikan lost function dari potensi produksi, maka Bank Sentral akan mampu membangun credibility serta adanya manfaat timeconsistency dari penggunaan policy yang akan menciptakan nilai tambah serta memberi kontribusi bagi pengembangan sasaran akhir kebijakan ekonomi makro yang lebih optimal dan efisien. Sebaliknya, apabila Bank Sentral mendahulukan pertimbangan pemberdayaan potensi output secara optimal dengan mencegah kerugian lebih banyak dari potensi produksi, maka 
sasaran akhir inflasi akan ditentukan secara lebih flexible dengan akibat memposisikan Bank Sentral menjadi tidak credible.

Berdasarkan kondisi sebagaimana telah dijelaskan diatas, maka merumuskan sebuah pemodelan yang memadai bukan merupakan pekerjaan yang mudah, tidak saja terkait dengan pilihan yang bersifat respon kebijakan moneter serta sasaran akhir yang ingin dicapai, tetapi juga bahwa sifat dari antar hubungan pada variable ekonomi makro yang diamati didasarkan oleh ketidak-pastian yang tinggi oleh berbagai kemungkinan terjadinya shocks. Maka ditengah keputus-asaan seperti itu, policy maker melakukan judgment berdasarkan informasi yang tidak termuat pada sebuah model ekonomi makro sebagai langkah terbaik yang difahami saat ini dalam praktek manajemen Bank Sentral.

\section{PERKEMBANGAN TEORI MONETARY POLICY RULE}

Perkembangan pustaka teori ekonomi makro telah memusatkan perhatian saat ini pada Philip curve dan peran serta kerangka kebijakan moneter yang dapat dirumuskan untuk mendapatkan fungsi optimal dari kurve Philip untuk stabilitas ekonomi dan pertumbuhan ekonomi, termasuk didalamnya perluasan lapangan kerja. Pendekatan kerangka kebijakan moneter untuk mencapai sasaran inflasi dan ouput dikenal sebagai monetary policy rule.

Pemodelan ekonomi makro yang sangat sederhana sebagaimana digagas oleh Taylor (1993) tidak saja menjadi praktek dalam lingkungan Bank Sentral di berbagai Negara, tetapi juga menjadi inspirasi bagi pengembangan model Taylor dalam berbagai pemodelan. Setidaknya selama kurun waktu sampai dengan akhir tahun 2000, telah berkembang 6 kelompok pemodelan yang mengadopsi pendekatan yang berbeda. Tabel 1.1 menunjukkan perkembangan pemodelan yang menjadi dasar bagi pengembangan Taylor monetary policy rule pada tahun mendatang.

Clarida, Gali dan Getler telah mengembangkan konsep Taylor rule dengan mengadopsi rational expectation dari Friedman, sehingga fondasi teori moneter yang dibangun Clarida, Gali dan Getler dikelompokkan pada The New Keynesian Theory. Policy Rule yang bersifat unrestrict dan kemudian diperluas dengan pemodelan makro ekonomi ditemukan pada Rotemberg dan Woodford (1998), yang mengkaitkan kebijakan suku bunga sebagai instrumen yang mempengaruhi fungsi konsumsi dan wealt.

Tabel 1.1 : Perkembangan Pemodelan Ekonomi Makro Monetary Policy Rule yang berbasis penggunaan instrumen suku bunga. 


\begin{tabular}{|c|c|c|}
\hline No. & Nama Pemodelan & Peneliti Yang Mengembangkan \\
\hline 1. & $\begin{array}{l}\text { Small scale model without rational } \\
\text { expectation }\end{array}$ & $\begin{array}{l}\text { Ball (1997), Ball (1998) } \\
\text { Rudebusch and Svensson (1997) } \\
\text { Svensson (1998) }\end{array}$ \\
\hline 2. & $\begin{array}{l}\text { Small scale model with rational } \\
\text { expectation }\end{array}$ & $\begin{array}{l}\text { Clarida, Gali, Getler (1997) } \\
\text { Fuhrer and Madigan (1997) } \\
\text { Haldane and Batini (1998) } \\
\text { Orphanides dan Wieland (1997) }\end{array}$ \\
\hline 3. & $\begin{array}{l}\text { Optimizing model with } \\
\text { representative Agent }\end{array}$ & $\begin{array}{l}\text { Chari, Kehou, McGrattan (1998) } \\
\text { Goodfriend dan King (1997) } \\
\text { King dan Woldman (1998) } \\
\text { McCallum dan Nelson (1998) } \\
\text { Rotenberg dan Woodford (1997) } \\
\text { Rotenberg dan Woodford (1998) } \\
\text { Svensson (1998) }\end{array}$ \\
\hline 4. & $\begin{array}{l}\text { Large Econometric model with } \\
\text { rational expectation }\end{array}$ & $\begin{array}{l}\text { Brayton,Levin,Tryon,William(1997) } \\
\text { Levin, Wieland, William (1998) } \\
\text { Tayolor (1995) } \\
\text { William (1997) }\end{array}$ \\
\hline 5. & $\begin{array}{l}\text { Historical or International } \\
\text { comparison }\end{array}$ & $\begin{array}{l}\text { Clarida, Gali, Getler (1997) } \\
\text { Judd dan Trehan (1995) } \\
\text { Orphanides (1997) } \\
\text { Taylor (1998) } \\
\text { Thuman, Alzola, Monisen (1998) } \\
\text { Waymark (1997) } \\
\text { Wright (1998) }\end{array}$ \\
\hline 6. & $\begin{array}{l}\text { Policy perspective on rule by policy } \\
\text { makers }\end{array}$ & $\begin{array}{l}\text { Blinders (1996) } \\
\text { Gramlich (1998) } \\
\text { Greenspan (1997) } \\
\text { Meyer (1996) } \\
\text { Yellen (1996) }\end{array}$ \\
\hline
\end{tabular}

Sumber : Taylor (1998).

\section{Design Pemodelan Monetary Policy Rule}

Pemodelan makro ekonomi policy rule yang digagas oleh McCallum (1987) dan Taylor (1993) dirumuskan untuk memenuhi kebutuhan perumusan kebijakan moneter yang bersifat praktis untuk pengelolaan moneter Bank Sentral. Dengan merumuskan policy rule yang sederhana diharapkan dapat dicapai sasaran akhir stabilitas ekonomi. McCallum (1988) merumuskan feedback rule yang relative sederhana yang juga dikenal sebagai monetary growth rule atau McCallum rule, yang memuat pertumbuhan uang primer yang ditentukan oleh perubahan output nominal. McCallum rule dijabarkan sebagai berikut. 


$$
\Delta b_{t}=\Delta x_{t}^{*}+\Delta v_{t}^{a}+\lambda\left(\Delta x_{t}^{*}-\Delta x_{t-1}\right)
$$

Dimana:

$b_{\mathrm{t}} \quad=$ uang primer

$\mathrm{x}_{\mathrm{t}} \quad=$ tingkat output nominal

$\mathrm{x}_{\mathrm{t}}^{*} \quad=$ target ouput nominal yang diharapkan

$\Delta \mathrm{x}^{*} \quad=$ konstanta yang menggambarkan pertumbuhan output nominal untuk periode 1 tahun

$\mathrm{V}_{\mathrm{t}^{\mathrm{a}}} \quad=$ rata-rata perubahan base-velocity.

McCallum mempergunakan $\lambda$ sebagai parameter positif yang menggambarkan simulasi dari arah perubahan output nominal terhadap pertumbuhan uang primer.

Berdasarkan arah perkembangan pasar keuangan internasional, serta sebagai akibat dari financial innovation yang sangat pesat, maka prediksi dengan mempergunakan monetary aggregate, sebagaimana telah dinyatakan sebelumnya, telah mulai ditinggalkan banyak negara. Bahwa berdasarkan kondisi demikian, monetary rule yang digagas oleh McCallum kurang mendapat tempat.

Taylor (1993) menawarkan pendekatan model monetary policy rule yang memuat sistem persamaan relatif sederhana, tetapi dengan mempergunakan pendekatan suku bunga sebagai fungsi reaksi dari deviasi inflasi dan output gap. Taylor mengembangkan model monetary policy rule untuk federal fund rate dan menghubungkannya dengan deviasi inflasi dan deviasi output. Rekomendasi Taylor untuk Federal Reserve Amerika Serikat sebagai berikut.

$$
i_{t}^{*}=\bar{i}+\gamma_{\pi}\left(\pi_{t}-\pi^{*}\right)+\gamma_{\gamma}\left(y_{t}-y_{t}^{*}\right)+\varepsilon_{t}
$$

Persamaan (2.2) dikenal sebagai simple monetary policy rule dari Taylor, yang memuat tingkat suku bunga sebagai fungsi reaksi, yang besarnya tingkat suku bunga ditentukan oleh deviasi inflasi $\left(\Pi-\Pi^{*}\right)$ dan deviasi ouput $\left(y-y^{*}\right)$, sedangkan $\gamma_{\Pi}$ dan $\gamma_{\gamma}$ adalah parameter yang nilainya ditentukan berdasarkan respon kebijakan moneter Bank Sentral.

Simulasi dari simple monetary rule dari Taylor (1993) dilakukan untuk mengkaji kemungkinan penerapan kerangka kebijakan moneter pada Federal Reserve Amerika Serikat sebagai berikut.

$$
\begin{aligned}
& i_{t}^{*}=4+1.5\left(\pi_{t}-2\right)+0.5\left(y_{t}-y_{t}^{*}\right) \\
& i_{t}^{*}=2+0.5\left(\pi_{t}-2\right)+0.5\left(y_{t}-y_{t}^{*}\right)
\end{aligned}
$$


Dimana:

$\mathrm{i}^{*} \quad=$ target nominal suku bunga Fed dalam nilai percent per tahun

$\mathrm{r}^{*}=$ suku bunga riel per tahun

$\Pi=$ nilai inflasi kuartal dalam periode 1 tahun

$\mathrm{y}_{\mathrm{t}}=\log$ dari riel GDP

$\mathrm{y}^{*}=\log$ dari potential GDP

$\mathrm{y}-\mathrm{y}^{*}=$ output gap yang merupakan deviasi secara prosentase.

Untuk setiap upaya penurunan inflasi sebesar 1\%, maka penurunan suku bunga Fed dapat dilakukan sebesar $1.5 \%$. Taylor mempergunakan asumsi keseimbangan pada sistem persamaan pada tingkat inflasi $2 \%$. Dengan demikian, apabila inflasi akan ditingkatkan menjadi $2 \%$, dengan asumsi output gap masih positif, maka dengan memberi bobot kenaikan pada output sebesar $0.5 \%$, maka suku bunga Fed akan ditentukan menjadi 1\%. Policy rule dari Taylor ini tampaknya lebih mendapat tenpat dibandingkan dengan policy rule dari McCallum yag mempergunakan money aggregate.

\section{Respon Kebijakan Monetary Policy Rule}

Pemodelan ekonomi makro monetary policy rule yang dibahas berikut ini mengasumsikan sebuah simple policy rule dari Taylor, tetapi dengan menyertakan sejumlah pemodelan yang berbeda dari sejumlah penulis. Perbedaan dimaksud dapat dilihat dari respon kebijakan yang memberi pembobotan berbeda pada deviasi inflasi dan deviasi output. Para peneliti tentunya memiliki dasar teori dan argumentasi yang mendukung mengapa mereka memilih pembobotan tertentu. Simple policy rule dari Taylor disajikan sebagai berikut. (Taylor, 1998).

$$
i_{t}=\rho i_{t-1}+g_{\pi} \pi_{t}+g_{\gamma} y_{t}+g_{o}
$$

Persamaan (2.5) menunjukkan simple policy rule dari Taylor, dimana $\mathrm{i}_{\mathrm{t}}$ merupakan suku bunga, $\mathrm{g}_{п}$ adalah respon deviasi inflasi, serta $\mathrm{g}_{\gamma}$ adalah respon deviasi output. Pengelompokkan pemodelan sampai saat ini menunjukkan terdapat 5 model pendekatan yang berbeda, sesuai dengan pendekatan model makro serta policy rule dan sasaran akhir yang dicapainya. Tabel 1.2 menunjukkan jenis policy rule dimaksud.

Tabel 1.2 : Perkembangan Pemodelan Ekonomi Makro Monetary Policy Rule yang berbasis penggunaan instrument suku bunga.

\begin{tabular}{|l|l|l|l|l|r|}
\hline No & Policy rule & $\mathrm{g}_{\Pi}$ & $\mathrm{g}_{\curlyvee}$ & $\rho$ & Nama Peneliti \\
\hline 1 & Rule 1 & 3.0 & 0.8 & 1.0 & Levin, Wieland, William \\
\hline
\end{tabular}




\begin{tabular}{|l|l|l|l|l|l|}
\hline 2 & Rule 2 & 1.2 & 1.0 & 1.0 & Batini and Haldane \\
\hline 3 & Rule 3 & 1.5 & 0.5 & 0.0 & John B. Taylor \\
\hline 4 & Rule 4 & 1.5 & 1.0 & 0.0 & Laurance Ball, John William \\
\hline 5 & Rule 5 & 1.2 & 0.6 & 1.3 & Rotemberg and Woodford \\
\hline
\end{tabular}

Perbedaan dalam mengimplemantasikan respon kebijakan policy rule di berbagai negara mengambarkan bahwa praktek kebijakan moneter tidak dapat dilepaskan dari kondisi nyata perekonomian di suatu negara yang berbeda dengan negara lain, serta sasaran akhir yang ingin dicapai baik untuk jangka pendek maupun jangka panjang.

McNelis yang telah melakukan penelitian tentang kemungkinan penerapan Taylor rule pada Bank Indonesia, telah merekomendasikan untuk memberi ruang gerak yang lebih besar pada inflasi dalam rangka mengurangi kerugian lost function dari potensi produksi dan angkatan kerja. Sebaliknya, Darsono et. al (1999) justru merekomendasikan untuk mencapai strict inflation targeting, dengan mengupayakan realisasi tingkat inflasi searah dengan target inflasi yang telah diumumkan Bank Indonesia kepada publik. Berbeda dengan McNelis, maka rekomendasi Darsono et. al akan mengabaikan kerugian lost function dari potensi produksi, dengan sararan untuk mencapai credibility Bank Indonesia, time-consistency serta macroeconomic performance sebagaimana di rekomendasikan oleh Rudebusch dan Svansson (2000).

\section{Pilihan Policy Rule untuk Indonesia.}

Simple policy rule dlam prakteknya di berbagai negara tekah di modifikasi menjadi paling sedikit meliputi 7 jenis pendekatan ( De Brower dan O'Regan, 2002). Pengembangan instrument rule dijabarkan sebagai berikut:

Rule 1 : Nominal income level rule :

$$
i_{t}=r^{*}+\pi_{t-1}+\gamma\left(p y_{t-1}-p y_{t-1}^{T}\right)
$$

Rule 2 : Nominal income growth rule:

$$
i_{t}=r^{*}+\pi_{t-1}+\gamma\left(\Delta p y_{t-1}-\Delta p y_{t-1}^{T}\right)
$$

Rule 3 : Price level rule

$$
i_{t}=r^{*}+\pi_{t-1}+\gamma\left(p_{t-1}-p_{t-1}^{T}\right)
$$

Rule 4 : Taylor rule : 


$$
i_{t}=r^{*}+\pi_{t-1}+\gamma_{1}\left(\pi_{t-1}-\pi^{T}\right)+\gamma_{2}\left(y_{t-1}-y_{t-1}^{*}\right)
$$

Rule 5 : Inflation only rule :

$$
i_{t}=r^{*}+\pi_{t-1}+\gamma\left(\pi_{t-1}-\pi_{t-1}^{T}\right)
$$

Rule 6 : Change rule :

$$
i_{t}=i_{t-1}+\gamma_{1}\left(\pi_{t-1}-\pi^{T}\right)+\lambda_{2}\left(y_{t-1}-y_{t-1}^{*}\right)
$$

Rule 7 : Constanr real interest rate rule :

$i_{t}=c+\pi_{t-1}$

Dimana:

i : tingkat suku bunga

п:tingkat inflasi

py: pendapatan nominal

$\mathrm{T}$ : target

$\mathrm{P}$ :tingkat harga

$\mathrm{y}$ :real income

$\mathrm{y}^{*}$ : ouput potensial

$c$ : parameter constant real interest rate

$\mathrm{\gamma}$ : parameter dari fungsi reaksi dari policy rule

Rule 1 sampai dengan Rule 7 adalah sejumlah pilihan yang dapat dipergunakan oleh suatu negara berdasarkan kondisi real perekonomian suatu bangsa, serta sasaran akhir yang ingin dicapai. Bahwa consensus yang ada saat ini adalah upaya untuk melaksanakan inflation targeting framework untuk mencapai sasaran akhir tingkat inflasi yang rendah dan stabil untuk membangun time-consistency serta kinerja ekonomi makro yang makin efisien dalam rangka menciptakan stabilitas ekonomi untuk mencapai pertumbuhan ekonomi yang lebih terarah.

\section{Monetary Policy Rule untuk Indonesia}

Bila mengikuti perkembangan terakhir dari pelaksanaan inflation targeting framework yang dilaksanakan oleh Bank Indonesia sejak persiapannya pada tahun 1999 sampai dengan efektif pelaksanaannya tahun 2005, maka tampak bahwa monetary policy rule yang diterapkan oleh Bank Indonesia dengan perencanaan inflasi yang semakin menurun dalam tahun 2006, 2007 dan 2008 belum dapat dicapai secara optimal. Data pada table 1 menunjukkan bahwa target inflasi Bank Indonesia tidak dapat dicapai sesuai dengan perencanaannya.

Tabel 1.1 : Target dan Realisasi Inflasi

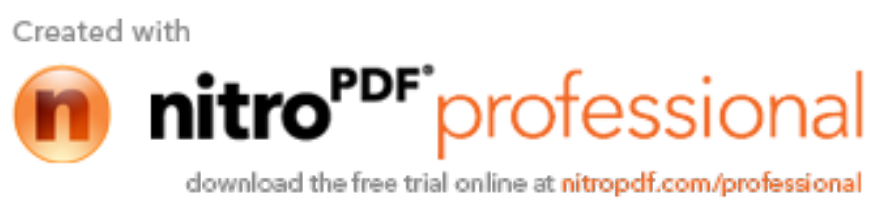




\begin{tabular}{|c|c|c|}
\hline Tahun & Target Inflasi & Realisasi Inflasi \\
\hline 2006 & $7 \mathrm{~s} / \mathrm{d} 9$ & 12.99 \\
\hline 2007 & $5 \mathrm{~s} / \mathrm{d} 7$ & 6.40 \\
\hline 2008 & $4 \mathrm{~s} / \mathrm{d} 6$ & 9.91 \\
\hline
\end{tabular}

Sumber : Bank Indonesia, Jakarta. 2008.

Kegagalan Bank Indonesia dalam mencapai realisasi inflasi dapat terjadi karena adanya ketidak-pastian yang tinggi dari shocks yang selalu datang lebih cepat dari perkiraan. Apabila dilihat dari sasaran akhir yang ditargetkan Bank Indonesia, maka jelas bahwa inflation targeting framework Bank Indonesia menuju pada target pengendalian inflasi yang semakin rendah, dari interval 7 sampai 9 menuju 4 sampai 6 point pada akhir tahun 2008.

Beberapa type shocks yang tidak diperkirakan sebelumnya adalah administered price dari kenaikan harga minyak BBM serta dampak dari krisis ekonomi Amerika Serikat yang berpengaruh terhadap pasar saham dan perdagangan ekspor Indonesia. Tetapi bahwa perubahan kebijakan moneter dari money aggregate ke bentuk Taylor policy rule telah dilaksanakan secara konsisten, dalam hal mana Bank Indonesia saat ini telah mempergunakan BI rate sebagai policy instrument dalam mempengaruhi sasaran akhir stabilitas ekonomi di Indonesia. Meskipun saat ini BI rate masih terpatok dengan harga 9.5 point, maka masih akan terdapat penurunan rate untuk mencapai sasaran inflasi yang lebih rendah, meskipun kebijakan penurunan BI Rate masih sering dikaitkan dengan kekhawatiran akan terjadinya Capital Flight, mengingat suku bunga domestic yang lebih rendah dari pasar suku bunga internasional (LIBOR) akan dapat memacu pelarian modal ke luar negeri, yang pada gilirannya dapat mempersulit likuiditas ekonomi nasional.

\section{KESIMPULAN}

Tulisan singkat ini hanya memuat garis besar perkembangan teori moneter yang digagas oleh Taylor (1993), yang menggagas pentingnya penggunaan rule dibandingkan dengan kebijakan moneter yang bersifat discretion. Konsensus yang ada saat ini menyatakan bahwa penggunaan policy rule paling sedikit bisa dicapai 3 manfaat besar yaitu credibility Bank Sentral yang dapat menciptakan nilai tambah tentang pentingnya forward looking expectation dalam rangka pengendalian inflasi, time-consistency yang sangat penting sebagai bagian dari perencanaan pembentukan sejumlah prilaku saat ini dalam membentuk masa depan yang lebih terarah, serta kinerja macro economic yang lebih optimal dan efisien. 
Berdasarkan informasi Tabel 1 tampak bahwa target inflasi yang ingin dicapai Bank Indonesia dan pemerintah, jelas akan menuju pada sasaran inflasi yang rendah dan stabil hingga mencapai angka antara 5 sampai 6\% pada akhir tahun 2008. Bahwa Bank Indonesia dalam mencapai target inflasi tersebut, tampaknya juga mempertimbangkan aspek lain yang berhubungan dengan posisi BI Rate dalam kerangka international capital mobility. Bahwa penggunaan instrument rule BI Rate yang semakin rendah, meskipun akan mencapai target inflasi yang diinginkan, tetapi pada sisi lain dapat membawa resiko pelarian modal karena suku bunga domestik yang lebih rendah dari harga pasar uang internasional memang akan membawa resiko pelarian modal, sehingga akan dapat mengancam cadangan devisa serta pada gilirannya akan berdampak pada pasar valuta asing di Indonesia.

Berdasarkan kondisi shocks yang beraneka jenis yang mengandung ketidak-pastian tinggi, maka inflation targeting framework yang di implementasikan saat ini di Bank Indonesia tidak seluruhnya berjalan sesuai dengan target inflasi dan output yang diinginkan, tetapi lebih banyak akan tampak pada judgment penganbil kebijakan yang juga harus mempertimbangkan situasi jangka pendek dari pergerakan pasar keuangan internasional, yang terkait langsung pada kepentingan untuk menjaga stabilitas nilai kurs tukar, sebagai bagian lain dari upaya untuk menjada stabilitas nilai rupiah.

Melihat kompleksitas permasalahan ekonomi Indonesia dewasa ini, maka simple policy rule yang diterapkan Bank Indonesia saat ini melalui daily inflation forecast tidak lagi memadai untuk dipergunakan. Diperlukan perluasan pemodelan dari Taylor Rule dalam bentuk unristrict policy rule, sebagaimana dengan menyertakan pertimbangan shocks termasuk peranan anggaran belanja pemerintah, perubahan harga bahan makanan serta external shocks termasuk perubahan tingkat suku bunga internasional serta harga minyak dunia. Tentunya penyusun sebuah pemodelan yang memadai untuk menjadi guide-line Bank Indonesia adalah sebuah pekerjaan tidak mudah, karena sebagian besar sumber inflasi tidak semata merupakan fenomena moneter, tetapi adalah bersumber dari sisi penawaran serta prilaku anggaran belanja pemerintah, yang sudah barang tentu diluar jangkauan Bank Indonesia untuk mengintervensinya.

\section{DAFTAR PUSTAKA}


Alamsyah Halim, Judha Agung and D. Zukverdy. 2001. Towards implementation of Inflation Targeting In Indonesia. Bulletin of Indonesian Economic Studies. ANU, Canberra.

Pohan, Aulia. 2008. Kerangka Kebijakan Moneter \& Implementasinya di Indonesia. Jakarta: Raja Grafindo Persada.

Batini, N and Haldane, AG 1999. Forward-Looking Rules for Monetary Policy. in Taylor John B, (ed). Monetary Policy Rules. Chicago: Univ. of Chicago and NBER.

Bernanke, Ben S. dan Reinhart, Vincent. 2004. Conduct Monetary Policy At Very Low Shortterm Interest Rates. American Economnic Review.

Ball, Laurence, 1998. Policy Rule For Open Economies. Reserve Bank Of Australia.

Clarida, Richard, Jordi Gali dan Mark Getler. 1997. Monetary Policy Rules in Practice, Some International Evidence. Center for Applied Economics. New York Ubiversity.

Darsono, Akhlis R Hutabarat, Rizki E Wimanda, Handayani dan Tri Yanuarti. 2002. Disain Monetary Policy Rule Untuk Indonesia. Direktorat Riset Ekonomi Dan Kebijakan Moneter Bank Indonesia. Jakarta.

Fuhrer, Jeffrey C dan Madigan, Brian F 1997. Monetary Policy When Interest Rates Are Bounded At Zero. Review of Economics and Statistics.

Gordon, De Brower dan James O’Ragan. 2000. Evaluating Simple Monetary Policy Rules For Australia. Reserve Bank of Australia.

McCallum, Bennet T. 1987. The Case For Rules in the Conduct of Monetary Policy. A Concrete Example. Economic Review.

McNelis, Paul D. 1999. Monetary Policy, the Role Learning and Inflation Targeting Implication For Bank Indonesia. Direktorat Riset Ekonomi Dan Kebijakan Moneter BI. Jakarta.

Rotemberg, Julio dan Woodford, Michael. 1999. Interest Rate Rules Ib Estimated StickyPrice Models. Dalam John B. Taylor, Monetary Policy Rules. Chicago University Press. Chicago

Rudebusch, Glan D dan Svensson, Lars E.O. 1998. Policy Rules For Inflation Targeting. Dalam John B. Taylor, Monetary Policy Rules. Chicago University Press. Chicago.

Sukada. 2008. Peranan Bank Indonesia Dalam Pengembangan Pembangunan Daerah. Seminar Disajikan Pada Dies Fak Ekonomi Univ. Udayana. Denpasar

Svensson, Lars EO. 2006. Inflation Targeting. Princeton University.

Tanuwidjaja, Enrico and Keng meng Choy. 2005. Central Bank Credibility and Monetary Policy in Indonesia. Journal of Policy Modeling.

Taylor, John B. 1999. Discretion Versus Policy Rules In Practice. Carnegie Rochester Conference Series In Public Policy. 